\title{
A NEGLECTED TESTIMONIUM (FRAGMENT?) ON THE CHALDAEAN ORACLES*
}

\section{INTRODUCTION}

The Chaldaean Oracles, their Platonic context and their influence on later Platonism have recently received fresh scholarly attention (from, for example, Polymnia Athanassiadi, Carine van Liefferinge and Ruth Majercik). ${ }^{1}$ But although an important quotation from the Oracles - in indirect speech - can be found in the anonymous Turin Commentary on the Platonic Parmenides (9.1-8), this latter does not seem to have received a great deal of attention in the scholarly literature on the Oracles. ${ }^{2}$ Thus it seems that the Commentary's importance with respect to the Oracles is either not fully realized or else undervalued. Probably because the piece of text is a non-literal, that is, non-metric, quotation, editors of the Chaldaean Oracles have rejected the notion that it constitutes an actual fragment, and have viewed it only as a testimonium or a text of reference. ${ }^{3}$ However, it will be argued that what we actually

* I would like to thank the Swiss National Science Foundation for generously supporting my work on this article. I also owe a debt of gratitude to both the anonymous referee and Luc Brisson for their valuable comments.

1 P. Athanassiadi, 'The Chaldaean Oracles: theology and theurgy', in P. Athanassiadi and M. Frede (edd.), Pagan Monotheism in Late Antiquity (Oxford, 1999), 149-83. C. van Liefferinge, La Théurgie. Des Oracles Chaldaïques à Proclus, Kernos supplément 9 (Liège, 1999). R. Majercik, 'Chaldean triads in Neoplatonic exegesis: some reconsiderations', CQ 51 (2001), 265-96.

2 As far as I can see, Athanassiadi (nn. 1 and 3) does not discuss it and van Liefferinge only mentions it once (n. 1, 176-7). There she cites the viewpoint that Porphyry was the first to harmonize the teaching of the Oracles with Neoplatonism (shown, according to van Liefferinge, by H. Lewy for the Porphyrian De philosophia ex oraculis haurienda, by P. Hadot for our Parmenides Commentary [thus apparently assumed to be Porphyrian], and by J. J. O'Meara for Porphyry's works in general). The context for this harmonization is the supposed interaction of theology (represented by the Oracles) and philosophy (represented by the Platonists). Generally speaking, van Liefferinge is concerned with qualifying the role usually attributed to Porphyry in the transmission of the Oracles and their theurgical system, and she gives the main credit for their insertion into the late Platonic philosophy to Iamblichus rather than to Porphyry. As far as the appreciation of the Commentary is concerned, she and others follow, not necessarily consciously, H. Lewy, Chaldaean Oracles and Theurgy. Mysticism Magic and Platonism in the Later Roman Empire, ed. M. Tardieu (Paris, 19782; 1st edn. Cairo, 1956) who, according to M. Tardieu's index locorum, cites the Commentary on half a dozen occasions in the footnotes to his massive work but does not really exploit it any further. Equally concentrating on the Platonists' adaptation of the Oracles, Majercik, however (n. 1), gives an analysis of the problem in relation to the role triads play in these systems. This shift of interest from theurgy to Platonic triads together with the strong belief that the Commentary is authentically Porphyrian lead her to give more weight to the Commentary than studies of the Oracles usually do (cf. 266-8, 272, 276, 278-80, 282-3).

3 Cf. É. des Places (ed.), Oracles Chaldaïques (Paris, $1989^{2}$ [CUF]), test. to frs. 3 and 26 and cf. also R. Majercik (ed.), The Chaldean Oracles. Text, Translation, and Commentary (Leiden, New York, Copenhagen and Cologne, 1989), comm. to frs. 8 and 10. Future editions of the Oracles should, however, include texts such as the one from the Commentary, even when they are transmitted only in a paraphrastic and non-poetic form. There are several other shortcomings and problems in the modern editions of the Chaldaean Oracles; some of them are listed by Athanassiadi (n. 1), 157-9 and ead., 'Byzantine commentators on the Chaldaean Oracles: Psellos and Plethon', in K. Ierodiakonou (ed.), Byzantine Philosophy and its Ancient Sources (Oxford, 2002), 237-52, esp. 238-9. 
have in the Commentary is a (piece of a) Chaldaean Oracle in prose form. Whether one prefers to call this a 'fragment' or a 'testimonium' depends on one's understanding of these terms. In order to avoid any confusion I shall use the term 'testimonium' here.

In any case, it should be clear that the relation that obviously exists between the Oracles and the Commentary is significant and deserves further study. But this relation is not one-sided. The Parmenides Commentary offers more than simply additional information on the Oracles in the form of a testimonium. For this testimonium should, as we will see, be mined for further information not only about the doctrines of the Chaldaean Oracles, but also, and perhaps principally, about the Commentator himself and his Platonic tradition. ${ }^{4}$ By attempting to make sense of the testimonium in the light of both the Oracles and the Commentary as a whole we shall gain additional insight into the interdependence of the two works (the common denominator being, of course, Plato's dialogue Parmenides). In this way, the larger context of the respective philosophies, and, above all, of the theory of first principles may become clearer.

This needs some further explanation. The more scholars move towards accepting that a modified and intellectualized concept of theurgy (as opposed to magic) operates in the Oracles, and that the Oracles should be seen in the doctrinal context of Platonism, the more they should seek to address the problems raised by passages - such as that of the anonymous Commentator-which do not easily confirm ready-made (and often flawed) ideas about the Oracles. This is all the more important because some scholars who take account of the anonymous Commentator's citation from the Oracles argue that only scanty conclusions about the Oracles can be drawn from such Platonic testimonies. ${ }^{5}$ These scholars maintain that such Platonic texts are biased. In contrast, I will not only treat the Commentary as a complementary source of the Oracles' doctrine, but also argue that it reveals through this citation much about its author, his attitude and philosophy. In this sense, then, the Oracles and Commentary should be seen as shedding light each upon the other. We should certainly not discount the testimony of the Commentator merely because he speaks as a philosopher rather than a doxographer and cites the Oracles in order to make a specific doctrinal point. After all, a bias in the citing author can sometimes help us interpret the text or fragment cited, provided we can identify the bias. By taking into account the citing author's interests and viewpoints, we are able to extract from his words the argument of the original source. And besides, even doxography done for its own sake is not necessarily to be trusted on all accounts. I think we should

${ }^{4}$ Such an 'indirect' approach might well complement more straightforward/classical attempts at exposing the anonymous author's philosophy or aspects of it. For examples of the latter, cf. P. Hadot, 'Fragments d'un commentaire de Porphyre sur le Parménide', REG 74 (1961), 410-38; id., 'La métaphysique de Porphyre', in Entretiens sur l'Antiquité classique XII: Porphyre (Geneva, 1966), 127-63; id., Porphyre et Victorinus (Paris, 1968), 1.102-43. J. Dillon, 'Porphyry's metaphysic of the One', in $\Sigma O \Phi I H \Sigma M A I H T O P E \Sigma$. Chercheurs de sagesse, Hommage à Jean Pépin (Paris, 1992), 356-66. G. Bechtle, The Anonymous Commentary on Plato's "Parmenides" (Berne, Stuttgart and Vienna, 1999), 181-220; id., 'The question of being and the dating of the anonymous Parmenides Commentary', AncPhil 20 (2000), 393-414.

${ }^{5}$ The generalization of such a pessimistic attitude towards the reconstruction of the Oracles' own doctrine is the risk that an editor of the Oracles would take if he were to reorganize the fragments according to provenance (instead of systematically), especially if he thinks that our two main sources, Proclus and Damascius, represent two conflicting understandings of the Oracles' theological system, which cannot possibly be reconciled. Such a reorganization of the collection according to the provenance of the fragments is suggested by Athanassiadi (n. 1), 158. 
be careful not to extend the problematic image we have of Aristotle as a reporter of other people's doctrines to all seriously engaged philosophers of antiquity. Taking these precautions, we should then be able to approach the evidence in a way that is usually looked upon suspiciously, that is to say, by deriving information about the Oracles' doctrine from what would normally be considered to be the Platonist context in which this doctrine is embedded (see below).

This discussion has two principal aims. First (1), it seems possible to draw some significant conclusions about the Commentary and its author from detailed analysis of the use the Commentary makes of the Chaldaean Oracles. The most important of these conclusions can be summarized as follows: (a) the formal (and other) uniqueness of the Commentary's citation of the Oracles isolates the Commentator from later tradition; (b) the Commentator's philosophical point in citing the Oracles is not so much about the noetic or any other triad but about negative philosophy, in other words, it is not primarily about the superstructure of the system but about the foundations; (c) the Commentator is engaged in a real philosophical discussion with the Oracles; (d) the Oracles are not a priori a Holy Scripture for the Commentator the way they are for the later Platonists; (e) the Commentator is reluctant to equate the Oracles' doctrine with his own philosophy so that we cannot speak of a typically 'Neoplatonic' exegesis; (f) and, finally, the two triads found in the Commentator, that is to say the Chaldaean triad in the report and the Commentary's own triad in the sixth fragment, are independent and even incomparable both from a formal point of view and as regards content.

Even though one or two of these points constitute no more than a shift of emphasis from points made by Hadot in his Porphyre et Victorinus (1968), my analysis and its conclusions nevertheless differ in important respects from Hadot's position. Certain of my arguments cast doubt on and even contradict some of his main conclusions about the Commentary's use of the Oracles. No more, but also no less. To be sure, in order to disprove Hadot's ascription of this use of the Oracles to Porphyry much more would be required than can be done here. Indeed this would necessitate a fairly safe reconstruction of Porphyry's interpretation of the Oracles, which is a difficult, if not impossible task, for reasons outlined below. To take only limited account of Porphyry's interpretation has nevertheless the advantage of permitting a perhaps more modest, but also more certain preliminary basis for further studies into the Commentary's relation to the Oracles. For a complete picture of the latter one would in addition to Porphyry also need a complete survey of the later comments on the Oracles, such as Iamblichus' and Proclus', and compare all of this material. But for the time being a preliminary to such a vast enterprise may be useful, in the form of a study of the Commentary's way of using the Oracles.

The second main aim of this article (2) is to flesh out some aspects of the Oracles' own doctrine of highest principles, which we may do more confidently in the light of our new appreciation of the Commentary and its relation to the Oracles. This will involve analysing some fragments of the Oracles in combination with the Commentary's fragment-like report or testimonium of Chaldaean doctrine. An attempt will be made to identify the general area (if not perhaps the precise point) in the Oracles which provides the source for the anonymous Commentator's testimony. This, in turn, will enable us to scrutinize this part of the Oracles from a new perspective. 
The Commentary's citation from the Oracles, as has long been remarked, can be linked both directly and more indirectly to several fragments of the Oracles, in particular to fragments 3 and 4 (and may be linked to others, I believe), whose contents it confirms and further elucidates. It constitutes evidence that cannot easily be ignored when dealing with the relevant sections of the Oracles. Furthermore, the text of the anonymous Commentator's citation, as we will see presently, reads like a slightly paraphrased, but essentially direct, quotation from the Oracles rather than like a vague second- or third-hand testimonium, and the only fact that prevents our text from being accepted as a fragment in its own right is the reported and not hexametric speech in which it is presented. This rather formal argument, however, can hardly justify the way in which this important testimonium has been generally underestimated in the editions and major studies of the Oracles. (In addition, even in the case of so-called fragments, questions may at least sometimes be raised about the degree of accuracy with which it is possible to determine formal status and 'directness' or 'indirectness' of a citation-all of these being typical problems in editing collections of fragments.) Apart from the fact that the citation is in reported speech, scholars have seen no reason to doubt that we are in the presence of a very reliable testimony concerning the Oracles. And yet, while the authenticity of the testimony has not been challenged, scholars have not until now seen fit to exploit the Commentary as an important source of information about the Oracles.

\section{THE ANONYMOUS COMMENTATOR'S TEXT FROM THE CHALDAEAN ORACLES}

Let us start by looking at the problematic passage from the Oracles at the beginning of the fourth fragment. It reads as follows (9.1-8):

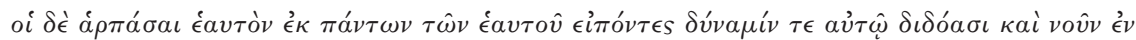

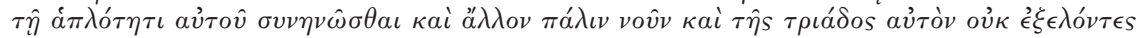

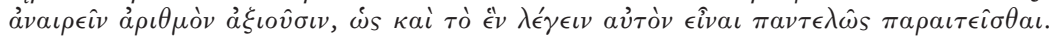

But those who have said that he has snatched himself away from all the things that are his, grant him that both power and mind have been unified in his simplicity, and also another mind, and, although they have not taken him out of the triad, they think that he does away with number, so that they entirely refuse to say that he is the One. ${ }^{6}$

The comments of the anonymous Commentator follow, beginning thus $(9,8-26)$ :

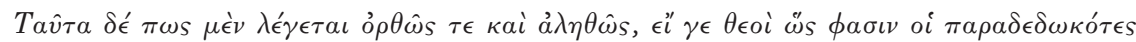

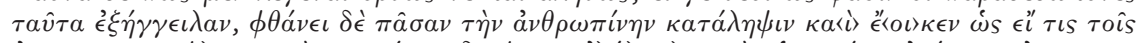

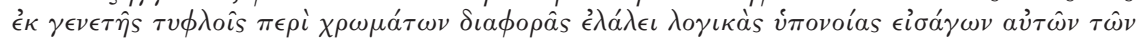

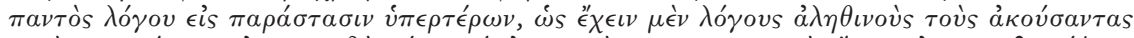

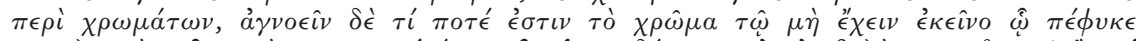

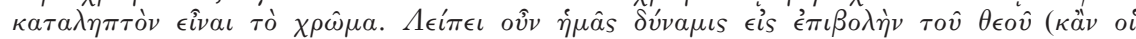

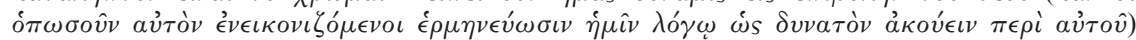

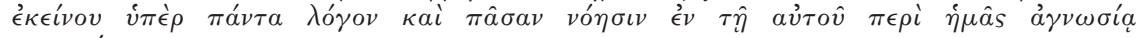

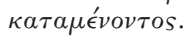

In a way, this is correctly and truly said, if gods, as those say who have passed on this tradition, really have proclaimed these ${ }^{7}$ things; but they (these things) outstrip every human apprehension and it is as if one spoke to people who are blind from birth about difference of colours,

${ }^{6}$ All translations of the Commentary are taken from my book: see Bechtle (n. 4, 1999). 
introducing ideas expressed in speech of the very things which are above all speech for their presentation, so that those who hear have on the one hand true words concerning colours, but on the other hand do not know what on earth colour is, since they do not have that by which colour is naturally apprehensible. We therefore lack the power for an act of direct apprehension of God \{even if those who in whatever way represent him explain to us through reasoning that it is possible to understand about him $\}$ since he stays above any reasoning and any conception in our ignorance of him.

\section{I.1. SOME PRELIMINARIES}

To state the obvious first: this citation from the Oracles means we have a terminus post quem for our Commentary insofar as it presupposes knowledge of some written version of the Oracles. No more, but also no less. Of course, the value of this information is slightly diminished by the fact that we do not know how to date the Oracles exactly. Skirting around the extremely complex debate which centres on the author(s) or - probably the apter word-editor(s), that is on the two Julians, father and son, it might for our purpose be sufficient to follow what has become a commonly accepted hypothesis and place the emergence of the Chaldaean Oracles as the collection from which our fragments stem in the later second century, perhaps around 160-180, that is to say approximately at the time of Marcus Aurelius' reign. Thus the anonymous Commentator is at best a contemporary of the Oracles, but probably later than they. This is the only 'hard' terminus post we possess, all others being dependent on our interpretation.

Next, we can perhaps leave out of the discussion here the even more vexed question of the relation between the Oracles and Numenius. It suffices to remark that everything seems possible and nothing certain as far as the existence or the direction of any influences are concerned. More generally speaking, if one had to formulate a hermeneutic principle, I consider it more likely that the philosophical current properly speaking would influence doctrinally the 'underworld' rather than vice versa. In the case of the Chaldaean Oracles, Gnostics, Hermetics and others, wherever a certain proximity to Platonism can be demonstrated, one might more readily attribute the main and ultimate responsibility for the philosophical points of the doctrine to the contemporaneous philosophers rather than suppose that those movements contributed to Platonism in any important original way. This does not mean that philosophers like Numenius or the anonymous Commentator were not sensitive to the religious environment of their time and that we cannot expect to find reflections of this in their writings. Beyond that, we can certainly expect from the philosophical side even critical discussions and reactions whenever the other side comes up with

${ }^{7}$ D. J. O'Meara suggests to me that the Commentator might make a more general point here, not only about the Chaldaean Oracles, but about divine revelations in general, so that he would express here his basic wariness concerning clear and affirmative doctrines transmitted as divine revelations. If this is correct one might translate such things instead of these things. For my purpose in what follows it is sufficient to suppose that the Commentator's reference is specific, rather than general (this applies in an analogous way to the expression those who have passed on this tradition).-The anonymous referee suggests that the importance of the phrase if the gods have spoken should not be overrated since it may be no more than a rhetorical mannerism. But there are three reasons why the $\epsilon i$ should not be taken lightly: (1) the $\epsilon i$ is reinforced by $\gamma \epsilon$ (if really, provided that), so that the conditional and hesitating character of the phrase is emphasized. (2) $\pi \omega s$ in the main clause qualifies the correctness and truth value of the preceding citation. (3) The introduction of the human transmitters, the $\pi \alpha \rho \alpha \delta \epsilon \delta \omega \kappa o ́ \tau \epsilon s$, adds further to our impression, if not of doubt, then at least of conscious and very strong circumspection on the part of the Commentator as far as the use of the fragment from the Oracles is concerned. 
more serious philosophical adaptations of Platonic doctrine (just like the Commentator does in the case of the Oracles, or Plotinus in the case of the Gnostics). If the philosophers could not have taken at least some of the more religious texts seriously enough to deal with them extensively, if in a critical way, the Chaldaean Oracles could in my view never have acquired the great importance they can be shown to have for authors like Iamblichus or Proclus. For them the interesting thing about the Oracles was the specific adaptation of some well-known Platonic doctrine into a more religious and supposedly divine context, thus providing ample material for their own interpretation. In this sense, then, we do indeed have a kind of two-way traffic in the matter of influences.

With regard to this priority problem, an interesting parallel to the relation between Numenius and the Chaldaean Oracles can be found in the relation between the anonymous Commentator and the Gnostic tractate Zostrianus (NHC 8.1). As regards the interpretation of Plato's Parmenides the presence of very similar material in the Commentary and Zostrianus has to be acknowledged. This evidence is parallel to material in Marius Victorinus that he was formerly thought to have derived exclusively from Porphyry (identified with the author of the Commentary), and therefore poses a problem. For Zostrianus (roughly to be dated to the first half of the third century and read in Plotinus' school), as must probably be admitted, is not only pre-Porphyrian and contemporary with Plotinus but is also very likely to go back to some Platonic source, that is, interpretative material concerning the Platonic Parmenides from the pre-Plotinian period. Considering the close affinities between the Commentary and Zostrianus, and in view of the hermeneutic principle stated above, the most straightforward hypothesis would be to make the Commentary this Middle Platonic source (thus to be dated to the late second or early third century). And even those who oppose this identification and leave the Commentary with Porphyry will hardly make Porphyry depend on Zostrianus but rather have to assume another Middle Platonic philosophical source common to both Victorinus and Zostrianus. But anyone who adopts this position indirectly admits that there are great resemblances between the Middle Platonic source and (Porphyry as) the author of the Commentary - for the latter is undeniably very close to Zostrianus and since Zostrianus and Victorinus require a common Middle Platonic source it is unavoidable that this source should be doctrinally very similar to the Commentary. To my mind, as long as it cannot be proved beyond reasonable doubt that Porphyry-who expressed Middle Platonic ideas himself - was the author of our extant fragment, the evidence would suggest that, rather than multiplying sources unnecessarily, one should view the anonymous Middle Platonizing Commentator and the author of the Middle Platonic source as one and the same. ${ }^{8}$

${ }^{8}$ On the Commentary in relation to Sethian Gnosticism cf. M. Tardieu and P. Hadot, 'Recherches sur la formation de l'Apocalypse de Zostrien et les sources de Marius Victorinus'/ " "Porphyre et Victorinus". Questions et hypothèses', Res Orientales 9 (Bures-sur-Yvette: Groupe pour l'étude de la civilisation du Moyen-Orient, 1996). Bechtle (n. 4, 1999), 248-9 n. 683; id. (n. 4, 2000), 408-12. J. D. Turner in C. Barry et al. (edd.), Zostrien (NH VIII, 1), BCNH: section "Textes" 24 (Laval, Louvain and Paris, 2000), 149-57. K. Corrigan, 'Platonism and Gnosticism. The anonymous Commentary on the Parmenides: Middle or Neoplatonic?', in J. D. Turner and R. Majercik (edd.), Gnosticism and Later Platonism. Themes, Figures, and Texts, SBL symposium series 12 (Atlanta, 2000), 141-77. I am very grateful to Luc Brisson for suggesting the following to me: "Mon idée de base est la suivante. Il faut distinguer entre a) le commentateur qui critique b) une interprétation de la fin de la première hypothèse du Parménide. Cette interprétation 


\section{I.2. THE COMMENTATOR'S UNIQUE MODE OF CITING THE CHALDAEAN ORACLES}

These preliminaries being stated, let us return to the Commentary's citation of the Oracles. As has long been remarked, we do have here a very interesting and absolutely unique way of citing them insofar as the divine Oracles, that is, the gods themselves who speak in them, are clearly separated here from those who have reported or compiled these revelations: the gods $(\theta \epsilon o \hat{\imath})$ as opposed to those . . who have passed on this tradition (oi $\pi \alpha \rho \alpha \delta \epsilon \delta \omega \kappa o ́ \tau \epsilon s ; 9.9-10$ ). ${ }^{9}$ It is in this part, the opening of the Commentator's exegesis, that we can make out this logical distinction

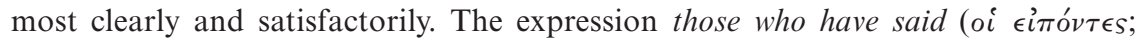
9.1-3), on the other hand, that is to say the subject on which the reported speech construction depends in the citation itself, might as such mean either the gods or the compilers, or even both. In view of what follows in the Commentary I have a certain preference for the editors, ${ }^{10}$ since they and their text seem to be the Commentator's only reliable source of information while he has perhaps some qualms about the divine origin of the actual words he cites (after all, he has to take a human's word for it). But perhaps the simplest and most reasonable course is to go one small step further and settle for an understanding that takes the those who have said impersonally meaning just they, the Oracles, as a text or collection of texts (necessarily compiled by someone), to which the Parmenides Commentator refers. In this hypothesis, he would introduce the distinction and further complication of supposed divine origin and human edition only in his own commentary a few lines later (9.8ff.). This would further underline the reliability and even the 'fragmentcharacter' that I believe this testimony possesses.

critiquée assimile l'Un de la première hypothèse au Père des Oracles Chaldaïques. Même si ce Père est au-dessus de tout le reste, on peut l'atteindre par le discours et par la pensée. C'est précisément ce que conteste le commentateur qui met l'Un de la première hypothèse au-delà de l'être et donc au-delà de tout discours et de toute pensée. Voilà pourquoi je pense que le commentateur est un post-plotinien et qu'il critique une interprétation médio-platonicienne du genre de celle qu'aurait pu soutenir quelqu'un comme Numénius dont la position s'accordait bien avec celle des Oracles Chaldä̈ques. Si tel est le cas, un Gnostique pré-plotinien aurait pu utiliser cette interprétation du Père pour décrire le premier dieu." Brisson's hypothesis depends on a clear-cut distinction between the (post-Plotinian) Commentary, on the one hand, and an earlier Numenian/Chaldaean environment, on the other. I think that the distinction, if it exists, is not nearly as clear-cut as Brisson requires it to be. However, I admit that the postulated similarities between the Middle Platonic source and the Commentator may well mean only that, that is to say similarity, and not identity. Thus the Commentary may be slightly later than the source. The Commentary may therefore be a text that was written at about the same time as Zostrianus, and it may indeed be that Zostrianus and the Commentator are involved in a sort of dialogue - a dialogue perhaps initiated by doctrinal problems or questions stemming from the philosophical and religious environment that is common to the Middle Platonic source, Numenius, and the Oracles.

${ }_{9}$ Cf. e.g., W. Theiler, Die chaldäischen Orakel und die Hymnen des Synesios, Schriften der Königsberger Gelehrten Gesellschaft, Geisteswissenschaftliche Klasse 18 (Halle [Saale], 1942) (repr. in id., Forschungen zum Neuplatonismus [Berlin, 1966], 252-301), 2. (253). Hadot (n. 4, 1966), 160-1 (in a response to Theiler); id. (n. 4, 1968), 1.107-8 and 2.93, n. 4. W. Theiler, 'Das Unbestimmte, Unbegrenzte bei Plotin', Revue internationale de philosophie 24 (1970), 291-2. P. Hadot, 'Bilan et perspectives sur les Oracles Chaldaïques', in Tardieu's edition of Levy (n. 2), 714. Bechtle (n. 4, 1999), 240-2.

${ }^{10}$ Cf. Bechtle (n. 4, 1999), 240. 


\section{I.3. THE DEBATE ON NEGATIVE THEOLOGY}

In any case, I agree with Hadot that it is very unlikely that the expression those who have said refers to Porphyry himself or to someone defending the same ideas as Porphyry as regards the Oracles and that our anonymous post-Porphyrian Commentator cites this Porphyrian philosopher and his exegesis of the Oracles in order to say that he does not believe in these Porphyrian tenets concerning the Oracles. For we should not complicate things unnecessarily and introduce three viewpoints when there are actually only two. The context makes it very clear that the anonymous author is directly engaged in an active philosophical debate with the text and the doctrine of the Oracles themselves and what they imply. He first presents the Oracles' tenets and then he expresses his doubts about certain parts of their thought (or we should perhaps rather say: about the way in which they expound their doctrine, that is the affirmative mode). What he says is that these Oracles in their affirmations about the highest principle may well be right (after all, we have divine authority for it, if that is correct, that is, if we believe the editors) but they really go too far with it all since no human being can actually understand these things. Therefore the mode of negations might be better adapted to human apprehension than that of affirmations, our Commentator suggests. This is a kind of meta-reflection on the prerequisites and conditions of important points of doctrine and constitutes to a certain degree a conscious philosophical criticism for which a modern observer might admire the Commentator. Instead of taking for granted the divine authority of the Oracles (that he certainly recognizes as such) and accepting without question what they say (and particularly how they say it), he stops for a moment to reflect upon our human philosophical means of attaining such supreme truth. From that point of view we should be much more reticent about affirming things concerning the highest principle than is the supposedly divine text on which he comments. Incidentally, we should not overlook the fact that in order to make his point about the superiority of negative over positive theology the Commentator chooses to pass silently over the negative doctrinal elements contained in his report of the Oracles (the snatching away and the non-co-ordination with number) and to concentrate only on what they do affirm. The reason why this fairly reasonable philosophical critique is a real possibility for our Commentator in the first place is that he is aware of the difference between the authority of the gods and the human expression and transmission of the divine text, and also that he expresses this awareness towards his reader. For it is easier to introduce reservations into human propositions than into divine revelations. The Commentator's attitude can be summarized as follows: if gods speak about gods, we can assume that what they positively say about themselves is correct, provided that the (human) transmission of it is correct, that is to say direct. But for humans to speak of the gods in a positive way is neither adequate nor possible: rather than affirm attributes about gods that none of the humans can possibly know, they must limit themselves to negating attributes. It is certain that our Commentator has reflected a great deal on the possibility of the relation between humans and the transcendent god. His distinction between the gods on the one hand and the editors on the other-insofar as we can make it out with respect to the Chaldaean Oracles - can therefore safely be assumed to represent the judgment of a thorough and balanced mind. 


\section{I.4. SIGNIFICANCE OF THE COMMENTARY AS A SOURCE OF THE CHALDAEAN ORACLES}

Apart from revealing a lot about our Commentator's philosophical personality and his preoccupations, all of this also implicitly makes clear the following point: if only we are prepared to consider our Commentator's seriousness in this explicit debate with such an essential text as the Oracles, then we must attribute much more importance to this quotation from the Oracles than ever before. I think that both the Commentator's diffident though objectively engaged attitude towards the Oracles' positive theology and his questioning as to the origin of the text he summarizes and uses, mean that we must have a reliable and fairly literal reformulation of an actual extract of the Oracles. What is more, the quotation the Commentator gives is specific and touches on a point of doctrine (supreme triad), although his immediate point is general and touches on the foundation of this doctrine (positive theology). This I take to be an indication that the report has not been adapted for a particular context or formulated to prove a particular point which the Commentator wishes to make, but which his source, the Oracles, does not. A clear sign that the latter is not the case is the fact that the report our Commentator gives actually contains some important aspects of the Oracles' own negative theology. Their specific form of negative theology, however, probably seems insufficient to our Commentator. As a consequence he takes the Oracles to propound essentially a positive theology. Hence we can conclude that our author cites the Oracles from first-hand knowledge and that the report is certainly not distorted but at least true to the sense. The very close parallels between the report and some of the fragments of the Oracles as they appear in our editions also support this thesis. If I am right, we are therefore in this case allowed to approach the evidence in a way that is usually looked upon rather suspiciously, that is, we may derive information about the Oracles' doctrine from what would normally be considered to be the Platonist context in which this doctrine is embedded (see above). Thus we can be clearer about-and even flesh out - the meaning implied in these Chaldaean fragments with the help of the material we have in the Commentary. We can thus hope to make some reliable inferences about the doctrine of the Oracles from the Commentary's report-inferences which allow us to make certain interpretations of the Oracles more probable than others. But this is a rare case. In most other instances I would stick to the hermeneutic principle of the majority of scholars working on the Oracles who always, especially when dealing with non-literal citations, allow for a varying degree of adaptation and insertion into the specific contexts of the later Platonist authors from whom our material is usually derived. ${ }^{11}$ For I am quite aware how much harm can be done by treating as a 'fragment' every passage which shows similarity to an attested fragment and then

11 Majercik (n. 1), 265ff. goes even further and suggests that all our information (including the literal fragments) has a Neoplatonic bias: "Since there is no independent text of the Oracles to compare with the Neoplatonic utilization and interpretation of this material ... reconstructing the original context and meaning of a given verse or verses (no less the meaning and intent of the Oracles as a whole) is difficult at best. What can be done with more confidence, however, is a reconstruction of Neoplatonic interpretation of the Oracles." Her aim, then, is to make a partial attempt at such a reconstruction that for her mainly turns on the Platonists' equations or harmonizations of the Chaldaean entities with their perceived Platonic, Pythagorean, Orphic, etc., equivalents. The first text she discusses with regard to this Neoplatonic interpretation of the Oracles is 9.1-8 from our anonymous Commentator, the same lines I take as reflecting authentic Chaldaean doctrine. 
using such 'new fragments' as evidence from which to build up an enlarged synthetic picture. ${ }^{12}$ I do not think, however, that we run such a risk here.

\section{I.5. THE STATUS THE CHALDAEAN ORACLES HAVE FOR THE ANONYMOUS COMMENTATOR AND THE CONSEQUENCES THEREOF}

Let us return for a moment to our more formal criteria. A reference to the Oracles distinguishing between gods and compilers, that is, the Julians/Theurgians - not to mention the reason that caused the Commentator to make this distinction-is unique. If we look at the introductory formulae to fragments (in any edition other than that of des Places) we see that the reference we have in the Commentator has no parallel. I have already sought to explain this unique phenomenon in terms of the special context we have here. Of course, as Lewy's useful survey of the mode of quoting the Chaldaean Oracles ${ }^{13}$ suggests, both formulae (gods and those who pass on the tradition) are commonly used, but the distinction our Commentator makes between these two options is specific to him. For all the Platonists who cite the Oracles the gods and the Theurgians are with regard to the Oracles inseparable. ${ }^{14}$ What is more important, the motivations and philosophical attitude of the Commentator and his relation to the Oracles as outlined here is certainly unique in our current understanding of the history of Platonism. Both points together separate our author most clearly from Proclan and Damascian interpretations of the Oracles. Not only do these Platonists recognize the divine origin of the text they cite without any second thoughts or reservations about the fact that the text is necessarily an edited one. They also concentrate on rather subtle interpretations of the evidence so as to fit it neatly into their own system. Therefore, the very sophisticated and detailed harmonization of concepts from the Oracles with those derived directly from these authors' exegesis of the Platonic dialogues plays an important role in their philosophies. We find none of that in the Commentary (though the anonymous author does make interesting use of a different triad from the Chaldaean triad later at the end of the sixth fragment [14.15-26]; but this is very different from what we have here in the fourth fragment and additionally only concerns the second state of Mind). ${ }^{15}$ A kind of 'divinization' of the Chaldaean Oracles, by which they become a type of Holy Scripture, cannot be found in the Commentary. Instead, for our author the Oracles' authority rests upon the hypothesis that we can really trust their divine origin. All this means that we do not find in the Commentator's engagement with the Oracles any elements (formal or substantial) typical of the treatments which the Oracles received at the hands of Iamblichus or Proclus (or Damascius), for which the basis - if we follow the communis opinio - was established by Porphyry. Instead, the Commentator's rather fresh, direct and fairly critical approach seems to be perfectly reconcilable with the hypothesis of a philosophical environment different from the one we are used to when dealing with the Oracles' reception in late antiquity. Such a non-standard environment might also be seen as reinforcing (without being required for) my assumption that we can be particularly confident about the fundamental

\footnotetext{
12 E. R. Dodds, 'New light on the "Chaldaean Oracles", , in Tardieu's edition of Lewy (n. 2), 697.

13 Lewy (n. 2), $445 h$ (gods) and $m$ (verbs like pass on the tradition).

14 Cf. Hadot (n. 4, 1968), 1.108, n. 2.

15 Cf. Bechtle (n. 4, 1999), 210.
} 
correctness of the Commentator's citation, especially as he is so concerned about the mode of transmission of his extract.

\section{I.6. PORPHYRY, TRIADS AND THE PARMENIDES}

If one wished to argue specifically against a Porphyrian authorship of the Commentary, one would have to work out in as much detail as possible Porphyry's interpretation of the Oracles insofar as it can be derived from his attested works. In a second step, one would then have to compare one's results to the doctrines of the Commentary. But Porphyry's understanding of the Chaldaean Oracles is in itself a very complicated affair, raising multiple problems. They are connected, first, with the fact that we do not know exactly from the second-hand knowledge we possess which of Porphyry's fragmentary or lost works are relevant here, and to what extent, and, second, with the question of how to understand texts such as Porphyry's Philosophy from Oracles or the De regressu — which are possibly relevant — as regards his interpretation of the Oracles. It is not possible for me to examine these manifold problems within the scope of this discussion.

Additionally, such a comparison between, ideally, attested Porphyry and the anonymous Commentator as far as their exegeses of the Oracles are concerned is, if not pointless, nevertheless not very helpful in determining the place of the Commentator in that regard. For from what I have said above, it should be clear that, unlike Hadot, ${ }^{16}$ I do not believe that a very elaborate picture of the Commentator's interpretation and adaptation of the Oracles - especially as regards triads ${ }^{17}$ — can be derived from the passage of the Chaldaean Oracles quoted by him, There are two main reasons for this.

(1) As I have argued above, our passage is a fairly literal transcription of what our author found somewhere in the Oracles without an attempt to assimilate to his own system the details of the doctrine reported (this does not mean he does reject the teaching of the Oracles). For his comments concentrate on the superiority of negative theology in view of the epistemological relation between the human and divine spheres and not on any details of the triad: negative theology, which constitutes a more modest approach for a religious person, is more appropriate to human knowledge than the straightforward and affirmative mode that presupposes more than human knowledge. All of this is a discussion of the basics: the Chaldaean triad is exploited only insofar as it presupposes as a whole-I have remarked upon the elements of negative theology in the Commentator's report of the Chaldaean Oracles - positive theology which our Commentator thinks is the wrong strategy.

(2) The second reason needs more thorough development. The difference (both as regards 'place' and contents) between the triad of the Oracles and the Commentator's own triad, to be found towards the end of the sixth fragment, is another clear hint that the Commentator does not exploit or interpret the Oracles. This is particularly true as we know that later Platonists (and possibly even Porphyry) equate the two triads, once they have changed the context from the first to the second hypothesis of the Parmenides (which Porphyry, of course, does not do). As regards the 'place' of the triad one could make the following remarks. In the fourth fragment the Commentator still deals with the first hypothesis. This in itself means two things. (1) The top triad

16 Hadot (n. 4, 1968), 1.97-8, 128-9, 258-9.

17 Cf. also the seminal article by M. J. Edwards, 'Porphyry and the intelligible triad', JHS 110 (1990), 14-25. 
(Father-Power-Intellect) we find in the Chaldaean Oracles stood most probably in the context of an interpretation of the first hypothesis of the Platonic Parmenides. (2) If our Commentator does not tell us otherwise (and he does not), we cannot assume that the Commentator's Existence-Life-Intellection triad in the sixth fragment-in the context of the second Platonic hypothesis - is the same as the Father-Power-Intellect triad as reported from the Oracles. What our Commentator makes clear is that, as an interpretation of the first hypothesis, the Chaldaean supreme triad does not make much sense. Even though there are negative theological elements in it, the kind of negative theology required by the first hypothesis must go much further and leave any positive theological aspect behind. The first hypothesis is for him not about what God is, but about the possibility, or rather impossibility, of our approach to him. This is also the reason why he does not reject the actual contents of the Oracles' triadic doctrine: it is not really false (we cannot tell anyway), but just out of place in the discussion of the first hypothesis that must really be about extreme negative theology. Hence the Commentator does not correct the Oracles as such, but only insofar as they propose their triad as an interpretation of the first Platonic hypothesis. Now, if we suppose that Porphyry followed the Chaldaean Oracles, as we know from Proclus ${ }^{18}$ and Damascius, ${ }^{19}$ and placed the Chaldaean triad at the very summit of his system (i.e., as an interpretation of the first hypothesis, a fact for which he is criticized by his successors), then our passage in the fourth fragment of the Commentary would be very difficult to account for if it were Porphyrian. This is not only made clear by the Commentator's own favourable attitude towards negative philosophical approaches to God, but also by the kind of motivation that guides our Commentator in setting the passage out and that we learn about in the remainder of the fourth fragment (9.8-10.35). On the whole, this suggests a view of the first hypothesis and its God that seems to me incompatible with what Proclus and Damascius tell us about Porphyry.

Some remarks with regard to the content of the triad may be appropriate in this context. The Chaldaean Father-Power-Intellect triad is different already in wording from the Existence-Life-Intellection triad the Commentator makes us familiar with just before our transmitted text stops (14.15-26), that is, in the author's discussion of the second Platonic hypothesis. This is no accident. For the Commentator places his triad on the level of the second Intellect or second state of Intellect. The triad explains how the constitution of this Intellect, that is the Intellect properly speaking, works. The triad does not concern, however, the first Intellect or first state of Intellect, but not because he would not even be found here. For although the first Intellect's place is really the first hypothesis, he is also present in the sixth fragment. The reason for this is that the Commentator develops his general concept of Intellect as an interpretation of the second hypothesis. And even though the first Intellect transcends Intellect and the noetic, he is Intellect nevertheless, namely insofar as he is a model or idea of actual Intellect. Thus the Commentator conceives of his highest principle as the principle of Intellect. Therefore even the principle (thus in some way Intellect) is treated in the second hypothesis, if not as its main subject. In spite of this fact, there is no talk here of this triad or even of the Chaldaean triad with regard to the first Intellect. A mention of the Chaldaean triad with regard to the first Intellect would at least have suggested some proximity between the two triads since they would have

18 In Prm. 1070,15-30 (Porphyry not actually named).

19 Pr. 2, 1.4-2.10 (Westerink-Combès). 
been mentioned in the context of the second hypothesis. But since this is not the case, I think we must consider these triads as entirely independent from one another.

It seems to be the case, then: (1) that the Commentator does not comment on the Chaldaean triad; and (2) that he does not integrate it into his own system; and (3) that when using his triad in the interpretation of the second hypothesis he is not in any way exploiting the Chaldaean triad-because these triads are completely different in the Commentary. If these statements are correct, then we no longer possess any indications of Porphyry's interpretation of the Oracles, as reconstructed by Hadot, or any hints of other late antique interpretations of the Oracles' triad in the context of the Parmenides that we know of. But how does the Commentary then make sense? One could hold that our Commentator in the course of interpreting the first hypothesis realizes that the Chaldaean supreme triad traditionally adduced does not work here. For the Chaldaean supreme triad basically affirms something about the highest principles, a state of affairs in need of some qualification or correction involving a higher degree of negativity. The Commentator does not pursue the triadic theme further since he is not forced to find a place for this triad. The Chaldaean triad as such is not his topic, only the fact that the conception of God therein is too affirmative. The application of the Sophist's positive triad Existence-Life-Intellection in the second hypothesis with regard to the second state of Intellect (it cannot be attributed to the first) is independent of the Chaldaean triad.

Thus considered our Commentary sets out problems to be solved by other (later) commentators: on the one hand there is no real integration of the highest Chaldaean entities, which is not acceptable for philosophers such as Iamblichus or Proclus; on the other hand the Chaldaean triad does not fit well into the first hypothesis. What is more, the place where it might fit, that is to say further down in the system, on the noetic level, is already taken by the triad from the Sophist. Porphyry's suggestion, then, did probably not solve the whole problem. Whatever his ideas might have resembled in detail (and even though he might well have assimilated the Chaldaean doctrine to the Parmenides interpretation and even equated the Chaldaean triad with the Sophist triad, as opposed to our Commentator), he could not find a definite solution as long as he accepted the Chaldaean triad-or more specifically, the Chaldaean Father - as representing the supreme principle as outlined in the first hypothesis of the Platonic Parmenides. In any case, I think that the situation for Porphyry was different from that of the anonymous Commentator: for Porphyry the Oracles are not a text to be treated in such a liberal manner and the Parmenides must be approached in a somewhat more technical way. The Oracles speak of this Father-Power-Intellect triad, and particularly of the Father, in the context of the first Parmenidean hypothesis. And the first hypothesis is the 'place' that seems to be the most convincing one for Porphyry, too, while at the same time he also postulates a negative theology. Perhaps Porphyry thought that by so co-ordinating the contradictory elements and claiming a strong negative theology, of which he could find the starting point in the Oracles themselves, he could respond adequately to the obvious problems someone like the Commentator must face. The Chaldaean positive principles, Porphyry might hold, are the subject matter of the first hypothesis, if only we get our negative conception about them right. These aspects of Porphyry's interpretation of the Oracles (and of the Parmenides) are reconcilable with Hadot's picture of Porphyry. But they are quite different from what we have in the Commentary. For Porphyry does fit the highest Chaldaean entities into his system, defends their place within the first hypothesis and might even have equated the triads from both the 
Sophist and the Chaldaean Oracles. The definite solution to the problem set out by the Commentator was of course found (probably by Iamblichus). It consisted of an equation of the two triads, but not in response to the first Platonic hypothesis (with the Father/Existence as supreme principle tout court), but as an exegesis of the second hypothesis (with the Father/Existence as supreme noetic principle, that is to say as monad) while Porphyry confused, probably consciously, the One and the monad. In line with such a solution one could of course also find a way out of Porphyry's co-ordination problem, while not reverting to a disintegrated view like that of the Commentator.

\section{THE CHALDAEAN TRIAD: SOME BASICS AND A PROBLEM}

In relation to my second aim I shall develop in what follows some aspects of the Oracles' own doctrine of highest principles. I shall take as a starting point the Commentary's fragment-like report or testimonium and the related fragments and texts. Thus it will be possible to give an even firmer basis to some of the assertions made so far-for example that the Chaldaean triad was originally developed in the context of an interpretation of the first hypothesis of the Parmenides. It will also be easier to place some of the presuppositions of our argument back into their context, for example the mixture of positive theology with some negative elements in the Oracles. This more safely grounded understanding of the doctrine of the Oracles' supreme triad might then serve others as a basis for further doctrinal comparisons with a variety of texts, be they earlier or later.

According to the Commentary's passage on the Oracles cited above we have to deal with the following Chaldaean entities. The Father, not named as such, but clearly the supreme principle from which the triad starts, unites in his simplicity both Power and Intellect, that is, both Power and Intellect can be joined to him so as to form a unified triad - and even a problematic second Intellect seems to have his place here. Despite being thus a part of the triad the Father is beyond (transcends) number and hence cannot be called the One. Moreover, at some point he has even left behind all things belonging to him, even the Power and the Intellect(s). This paraphrase of the Commentator's text separates more clearly than the sentence in the Commentary the positive doctrine from the negative theological reservations the Oracles also seem to introduce. But the meaning is perhaps clearer when put this way. For our Commentator the negative qualifications must have looked like minor concessions or modifications in what was overall a very affirmative design of some four entities: (1) the Father/One, although it is better not to use such terms since he really transcends them; (2) a Power and (3/4) two Intellects, co-ordinated with the supreme principle, but left behind by him at some point. The two Intellects may strike us as being very odd indeed. J. Dillon has written an interesting article on this problem, starting from a passage in Arnobius' Adversus Nationes (2.25). ${ }^{20}$ There we can distinguish a God, princeps rerum, a pair of Intellects, mentes geminae, and a Soul. This describes, according to Dillon, the system of the Oracles, with a supreme principle above a dyad of two Intellects that are on the same level, though with differentiated functions and therefore some hierarchy between them (a concept somewhat parallel to Eudorus and Philo, Dillon argues). He connects this evidence with lines 9.1-8 from our Commentary and interprets the Father as the supreme principle, followed by the

20 J. Dillon, 'The concept of two intellects: a footnote to the history of Platonism', Phronesis 18 (1973), 176-85. 
Power and Intellect from the triad, taken together (which I think would be quite strange), as first or senior Intellect, containing and contemplating the Ideas, and, finally, the 'other Intellect' as the second or junior Intellect, using the Ideas as patterns to create, and being therefore demiurgic. Dillon suggests that this system constitutes a Neoplatonic interpretation of the Chaldaean hierarchy that may not have correctly grasped the functions of the two Intellects.

\section{II.1. MORE INFORMATION ON THE CHALDAEAN TRIAD}

To solve the riddle we should now turn to some other fragments from the Oracles - firstly fragments 3 and 4, and then fragments 7 and 8:

Fr. 3

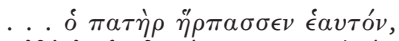

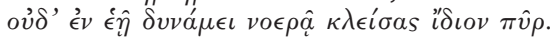

... the Father has snatched himself away without enclosing his own Fire in his intellectual Power.

Fr. 4

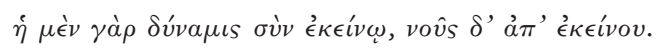

'For Power is with him, but Intellect is from him.'

This evidence should be taken together with fragments 26-7 where-provided that we reconstruct them correctly from the later Proclan and Damascian contexts in which they are embedded - the Father is described as triadic Monad or Monad ruling or leading the triad at the top of which it is placed. What we have, then, is the intelligible triad as ruled by a Monad; the latter is to be identified with the Father insofar as he prefigures or precontains this triad over which he presides. The triadic Monad means that the Father is closely linked to Power, the second and generative element in the triad (cf. also fr. 5: Father, i.e., first transcendent Fire, engages his Power not directly in creation, but only indirectly by Intellect), and eventually results in Intellect, that comes to be from the Father (cf. again fr. 5-and fr. 6: the two Intellects are separated merely by the membrane; cf. also fr. 50). Thus the Father being himself intelligible (cf. also fr. 1) as precontaining Intellect (fr. 20 bis) is everything (as source of everything, cf. fr. 7 and 10), though in an intelligible manner (fr. 21), since we are on the level of the intelligible triad prefigured by him (with the triad in turn prefiguring or precontaining everything, at least intelligibly [cf. also fr. 28]). So far this evidence mainly confirms and elucidates the information provided by the Commentator. But fragment 3 provides us with further information: instead of the usual static description some hints at the dynamics of the system are offered. As I have argued elsewhere, the Chaldaean system does not present a form of derivation theory that starts the process with the Father, the One Fire; instead it is turned upside down and starts with something that is strictly speaking already secondary and from which the Father retreats. ${ }^{21}$ Therefore the Oracles seem to present a contraction model of derivation, whereas the anonymous Commentator uses an expansion model.

${ }^{21}$ Bechtle (n. 4, 1999), 239. Bechtle (n. 4, 2000), 407. 
But first things first. The process really starts with the snatching away of the Father. Before, and this is the departure point, he is a triadic Monad, full with Power and Intellect, thus being himself the potentiality of actual Intellect, that is to say, a first and still full monadic moment, that is to say, all that potentially noetically is. This, the pre-existent Chaldaean triad, is the Father and first entity, but in its completeness, in its full threefold unity of being. And this is too much-some distinction is required if anything is to come into being (this idea is by and large also expressed in fragment 5). Therefore the Father, perfect unity, snatches himself away from this pre-existent fullness. He leaves behind the intellective power only, that is not the same as Power, but rather the seed from which the second Intellect can spring by interaction with Power. This means that he leaves behind that which will become actual second Intellect, precontained in the threefold unity of the Father. This is, by the way, the reason why even the Father himself having withdrawn can be called Intellect, though he must really be the first Intellect as principle of Intellect. The second Intellect, or the third element of the triad, is constituted by this intellective power that must have some similarity to a reduced monad (emptied of the Father's oneness although bearing some similarity with him and being thus the starting point and first element of the constitution of the second Intellect), or even be monad and dyad together. For the triadic Monad and Chaldaean triad is the full monad. And once the full monad has lost the pure unity, that is to say the Father's Fire identical to the Father and to the highest principle properly speaking, that is, the first Intellect, there can only remain a reduced monad - that has now made space for a dyad — which is the starting point of second Intellect, provided that it interacts with a dyadic principle. The latter is represented as Power and somehow symbolizes the Indefinite Dyad or Intelligible Matter that must apparently be conceived of as being closely linked to the Father (the expression intellective power might thus perhaps be taken to include both monadic and dyadic moments). Therefore, we begin with a state in which the three elements of the triad are undistinguished in a full Monad and represent as such the supreme entity of the Oracles in the form of the Chaldaean triad. Next we reach a state of total distinction of the individual elements of the triad, with the third element having become the second Intellect, that is constituted as actual Intellect (this is, I take it, the process that is described in fragment 5 of the Oracles, too: first the triad, but the need for coming into being necessitates two distinct Intellects that, even in their distinct state, remain very much related and must therefore be separated by a membrane [fr. 6]). The first principle is the pure Father, characterized by Fire, its true hypostatic identity as isolated pure One and first Intellect. Power as second element of the triad has its function insofar as it allows the generation of the second Intellect according to the first Intellect from that intermediate stage called intellective power.

\section{II.2. A SOLUTION OF THE PROBLEM}

If we look back, then, we do not find the Father as a supreme principle above a dyad of two Intellects, the first to be identified with the Power and Intellect, or even simply the Intellect, of the triad, the second being another Intellect. We should rather identify the Father, although he is a supreme principle, with the first Intellect. Next, Power, closely connected with the Father, is the dynamic principle and the condition for the coming into being of the second Intellect, that is, the element of Intellect in the triad, i.e., the paternal Intellect. Both Intellects are Fathers according to fragment 
50, and the Power between them must then be Hecate. At this stage we should have a look at fragments 7 and 8 :

Fr. 7

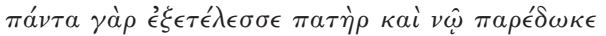

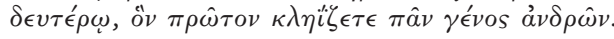

For the Father has perfectly accomplished all things and handed them over to the second Intellect, which you - the whole human race - call the first Intellect.

Fr. 8

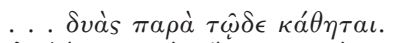

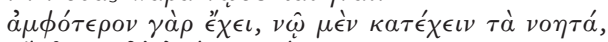

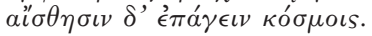

. . . beside this one sits a dyad. For it has each of these two functions: it contains by means of intellect the intelligibles and introduces sense-perception into the worlds.

We understand now that the Father's perfect accomplishment must refer to his retreat from the triad, since he thereby first launches the process of coming into being. But since he does not intervene any further, having snatched himself away and being beyond, being with his Fire alone, he gives everything to the second Intellect, who is the demiurge. The latter can also be conceived as a dyad because of his double function: on the one hand containing the intelligibles as patterns for creation, and on the other hand actually creating. That by which the dyad sits can, but need not necessarily, be identified with the first Intellect or Father, who would then be acting as the monadic principle of this dyad, not really involved, but totally indispensable. Fragment 5 of the Oracles confirms this: only the Intellect that is derived from Intellect is the demiurge, while the latter Intellect does not engage its Power in creation.

\section{II.3. THE PARMENIDES, THE COMMENTARY AND A PLACE FOR THE TESTIMONIUM ON THE CHALDAEAN ORACLES}

Let us recapitulate. According to our interpretation of the Chaldaean evidence as sketched out above, there can be no substantial doubt that the Chaldaean triad and its dynamics are derived from an interpretation of the first (and second) hypotheses of the Platonic Parmenides. Furthermore, the mixture of positive and negative theology (cf. also fragment 1, where only a negative approach can achieve some notion of the highest entity that is depicted in a comparatively positive way) and other peculiar features of the Oracles' doctrine can be accounted for if the latter can be reconstructed in the way explained above. For only after the withdrawal of the Father from the triad do we have real negative theology as suggested by the first Platonic hypothesis to a Platonist reader of the time. If, however, the first Intellect is seen together with the triad its mode of description is instead affirmative.

What, then, about our Commentator's testimonium? In the light of our reconstruction of the Oracles the Commentator's report can now be seen to fit very well with our picture of the Oracles' doctrine. The former even further confirms the latter if we read it in the right way. Power and Intellect, as united with the Father's simplicity, form together the Chaldaean triad that features so prominently in the 
Oracles and in the Commentary. But since in the undistinguished state of the triad Intellect is only an aspect of the threefold Monad - which is in turn an indication that the Monad, the Father, is also Intellect, in particular as first Intellect and principle of Intellect - and thus is only a part of the undistinguished full triad, this Intellect as aspect is not yet the actual demiurgic Intellect. Only when the triad is looked at in its distinguished state, once the Father has withdrawn and Intellect been constituted - with a membrane between them - can Intellect as an element of the triad be identified with second Intellect as an autonomous reality, not as an aspect or part of the Father in his threefoldness. From an integrated element of the Chaldaean supreme triad Intellect has become its own hypostasis second to the Father, who is now independent and even isolated with his own Fire. I take it, then, that the Commentator alludes to this very fact: first, Intellect is really only an aspect of the threefold Monad, the Father. Only once this triad has been externalized and come into being, can the supreme triadic entity be said to split into two distinct Intellects: the first, being totally beyond in its Fire, and the second, demiurgic paternal Intellect, the 'other Intellect' of the Commentator-with Hecate in between. And this is correctly termed by the Commentator 'and again another Intellect' since it has no longer anything to do with Intellect as integrated in the triad, or with the first Intellect. Thus the awkwardness of the Commentary's citation is due to the fact that the two ways of considering the Chaldaean triad are mixed: on the one hand the integrated triad that is really a triadic Monad precontaining Father-Power-Intellect, and on the other hand the state after the first coming into being with three individually distinguished entities: (1) Father, i.e., first Intellect; (2) the median principle; and (3) Intellect proper, i.e., second Intellect. The Chaldaean triad in its undistinguished state represents above all the triadic Monad, that is to say the Father, principle of Intellect and first Intellect, so that the Commentator introduces actual second Intellect as if it were another or new Intellect because the triad as Monad in this view only represents the first and does not automatically yield or imply the second, in particular as an own hypostasis. This is especially true from the Commentator's standpoint since he does not himself use, and may be less acquainted with, the contraction model of derivation. Thus, in order not to leave out an entity as essential as the Chaldaean second Intellect, the Commentator lists it explicitly. And we should also not forget in this context that he wants to make a point about positive philosophy, a point reinforced by a second Intellect here. In any case, I think that we have in the Commentator a very precise paraphrase of some section in the text of the Oracles, and this text might even have been, or must have been similar to what is expressed - admittedly in a creational context —in fragment 5 of the Oracles:

Fr. 5

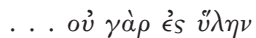

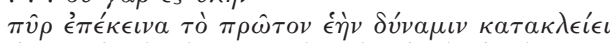

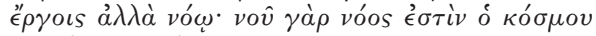

$$
\begin{aligned}
& \tau \in \chi v i ́ \tau \eta \text { supiov. }
\end{aligned}
$$

... for the first transcendent Fire does not enclose its own Power in matter by means of works but by Intellect. For Intellect from Intellect is the artificer of fiery cosmos."

In the first part of the phrase we have the typical ambivalence of negative and positive theology in the undistinguished Chaldaean triad. In the second part we have the Intellect from Intellect, that is to say the second Intellect that creates the world 
according to the image of its own model, the first Intellect and transcendent Fire. The Intellect from Intellect may well represent the 'other Intellect' of the Commentator, now that the triad and the Intellects are distinguished for the purposes of creation. Of course, our argument does not depend in any way on this precise identification that is given only exempli gratia.

Berne / Paris

GERALD BECHTLE gerald.bechtle@philo.unibe.ch 